\title{
Brazilian ground pearl damaging blackberry, raspberry and blueberry in Brazil
}

\author{
Pérola-da-terra causando danos em amoreira-preta, framboeseira e mirtileiro no Brasil
}

\author{
Caio Fábio Stoffel Efrom ${ }^{\mathrm{I}}$ Marcos Botton $^{\mathrm{II}}$ Geraldine de Andrade Meyer $^{\mathrm{III}}$
}

\section{-NOTE-}

\section{ABSTRACT}

The Brazilian ground pearl, Eurhizococcus brasiliensis (Wille, 1922) (Hemiptera: Margarodidae), is a subterranean, polyphagous scale insect native of Southern Brazil that feeds on a variety of different vineyard plant species (Vitis spp.). In this study, it is reported three new plant hosts of the species. In 2007 and 2010, infested plants were documented in

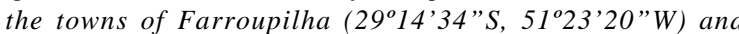
Vacaria (28'26'30"S, 50'52'59”W) in Rio Grande do Sul, Brazil. Specimens of the ground pearl were found in the roots of three cultivated berry plants: blackberry (Rubus spp.), raspberry (Rubus idaeus L.) and blueberry (Vaccinium sp.). Observed symptoms included: chlorotic leaves, gradual wasting, reduced production, and mortality. Given the increasing popularity of berry orchards in the region, this study serves as an alert for farmers to avoid establishing them in areas infested with the ground pearl and to check for the insects in the root cuttings used to establish berry crops.

Key words: Eurhizococcus brasiliensis, Rubus spp., Rubus idaeus, Vaccinium spp.

\section{RESUMO}

A pérola-da-terra Eurhizococcus brasiliensis (Wille, 1922) (Hemiptera: Margarodidae) é uma cochonilha subterrânea, polífaga, nativa do sul do Brasil, que se alimenta de diversas espécies vegetais causando prejuízos, principalmente à cultura da videira (Vitis spp.). Nesta comunicação, três espécies vegetais são relatadas como novos hospedeiros da praga. Em 2007 e 2010, plantas infestadas foram registradas nos municípios de Farroupilha (2914'34"S e 51 23 '20"W) e Vacaria (28'26'30"S e 5052'59”W), RS. Exemplares da cochonilha foram encontrados em raízes de amoreira-preta (Rubus spp.), framboeseira (Rubus idaeus L.) e mirtileiro (Vaccinium sp.). Os sintomas observados foram folhas cloróticas, definhamento progressivo, diminuição na produção e morte das plantas. Devido à ampliação do cultivo de pequenas frutas na região, essa informação serve de alerta aos produtores para que evitem o plantio em áreas infestadas com a cochonilha e observem a presença do inseto no material vegetativo utilizado para estabelecer o cultivo de pequenas frutas.

Palavras-chave: Eurhizococcus brasiliensis, Rubus spp., Rubus idaeus, Vaccinium spp.

Blackberry (Rubus spp.), raspberry (Rubus idaeus L.), blueberry (Vaccinium spp.), and other berry plants are increasingly popular crops in Brazil, where they are prized by consumers for the fruits' nutraceutical properties (ANTUNES, 2002; PAGOT \& HOFFMANN, 2003; PAGOT, 2009). Berry crops are a popular alternate source of income for small-scale farmers in the "Serra Gaúcha” and "Campos de Cima da Serra” regions, offering significant economic returns on small investments in time and space and thereby helping keep farms profitable.

The state of Rio Grande do Sul is the largest blackberry producer in Brazil, with approximately 200ha planted. Half of this is in the township of Vacaria and the rest in the Serra Gaúcha and Campos de Cima da Serra regions (PAGOT, 2009). Approximately 100ha of blueberries are cultivated in the state. The cultivation

IFundação Estadual de Pesquisa Agropecuária (Fepagro), Vale do Taquari, Taquari, RS, Brasil.

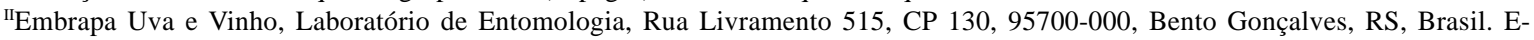
mail: marcos@cnpuv.embrapa.br. *Autor para correspondência.

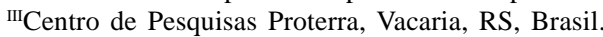


is distributed as following: 30ha in Vacaria (Highbush blueberries), 20 and 10ha (Rabitteye blueberries) in the Caxias do Sul and Pelotas regions, respectively, and the remainder in small, scattered holdings throughout the state (PAGOT, 2009). Roughly 40ha of raspberry are cultivated in Brazil: 10ha in a township of Vacaria and smaller patches in the Serra Gaúcha (PAGOT, 2009).

Berry cultivation is relatively new in Brazil, where pest management remains as one of many technical hurdles (ANTUNES, 2002; ANTUNES, 2007; NAVA et al., 2007; NINO et al., 2007; ANTUNES, 2008; PAGOT, 2009). In turn, a leading obstacle to effective pest management is native pests that co-occur with berry plants, first reducing production and subsequently causing mortality.

The Brazilian ground pearl, Eurhizococcus brasiliensis (Wille, 1922) (Hemiptera: Margarodidae), is a subterranean scale that attacks the roots of cultivated and wild plants (GALLOTTI, 1976; SORIA \& GALLOTTI, 1986; BOTTON et al., 2004). While several annual and perennial plant species are hosts, the most severe damage is observed in vineyards (BOTTON et al., 2004). Other temperate zone fruit trees, like apple and peach, are also attacked (BOTTON et al., 2000). The species is mostly known in southern Brazil (where it is believed to be native; BOTTON et al., 2000), in São Paulo state (LOURENÇÃO et al., 1989), and more recently has been documented in the São Francisco Valley, in Petrolina, in the state of Pernambuco (HAJI et al., 2004). The ground pearl lives in roots and only damages plants in the juvenile (nymph) phase, since adults lack mouthparts (BOTTON et al., 2004).

In 2007, the Brazilian ground pearl was observed attacking a blueberry (Vaccinium spp.) (Ericaceae) orchard in Vacaria (28 $26^{\prime} 30^{\prime}$ 'S, 5052'59”W), where it reduced production by approximately $20 \%$ and killed young plants. In October 2010 the ground pearl was observed on various berry species grown on an organic farm in Farroupilha

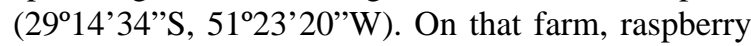
(Rubus idaeus L.) (Rosaceae) plants showed both mortality and reduced growth. Sampling of two plants, selected at random from each of the twenty $30 \mathrm{~m}$ rows, for a total of 40 plants, revealed that $85 \%$ had ground pearl in the roots. The species was also found to be present and contributing to a general decline in blackberry (Rubus spp.) (Rosaceae) and blueberry plants. Analysis of the roots of these plants revealed more than 50 cysts per plant, in addition to $\boldsymbol{E}$. brasiliensis eggs, nymphs, and mobile females in the soil and roots of the three species. Collected specimens were deposited in the Embrapa Grape and Wine entomological collection (AZEVEDO-FILHO et al., 2007). This note represents the first report of the association of $\boldsymbol{E}$. brasiliensis with berry species in Brazil. In Colombia, Eurhizococcus colombianus has been documented in the roots of the Andes berry (Rubus glaucus Benth.)(KONDO, 2001; BEN-DOV, 2005).

Symptoms of $\boldsymbol{E}$. brasiliensis attack included chlorotic leaves with gradual wasting, reduced production, and mortality, all of which combine to make the crop nonviable in infested areas (Figure 1). In Farroupilha and Vacaria, the ant species Linepithema micans Forel (Hymenoptera: Formicidade) was associated with the cysts. The same association has been documented for ground pearl in vineyards in Bento Gonçalves, Rio Grande do Sul. L. micans may be responsible for transporting the first-instar nymphs of $\boldsymbol{E}$. brasiliensis (phoresis) to new regions of the host plant or to other plants (SACCHET et al., 2009).

The study site in Vacaria is located near a vineyard infested with the scale. Brazilian ground pearl has also been observed in Rio Grande do Sul in docks and sorrels (Rumex spp.). In both cases, it is believed that the ground pearl was present on native host plants in the area before fruit crops were established.

Controlling Brazilian ground pearl in berry plants is complicated by the fact that these crops are commonly grown on organic farms. In vineyards, neonicotinoid insecticides are currently used against the ground pearl (TEIXEIRA et al., 2002; BOTTON et al., 2010b). Likewise, plant coverage (BOTTON et al., 2010a) and organic fertilizer (GARRIDO et al., 2008) can be applied to infested areas, as they are in vineyards. In Vacaria, mortality in the Bluecrop (Highbush) and Florida (Rabbiteye) varieties of blueberries only attacked localized groups of younger and less vigorous plants. In that case, to avoid further losses, in 2007, 25\% thiamethoxam was applied twice at a dosage of $3 g$ plant $^{-1}$, with a 60-day interval between treatments. This dosage was adjusted by one of the authors from recommendations for the insecticide's use in vineyards. In 2008, a single dose succeeded in controlling the ground pearl and a second dose was not applied. No chemical treatments were used on the organic farm at Farroupilha. Instead, maintaining plant coverage, organic fertilizer was applied, and neem (Azadirachta indica) was added to the soil via irrigation around the base of the plants. The results were unsatisfactory, and the raspberry crop in that area was eradicated due to reduced fruit production.

This study represents a clear warning for berry farmers and agronomists and provides some preliminary recommendations for establishing berry orchards in Brazil. Berry crops should not be established in, and saplings should not be used from, areas known to be infested with the Brazilian ground pearl. 


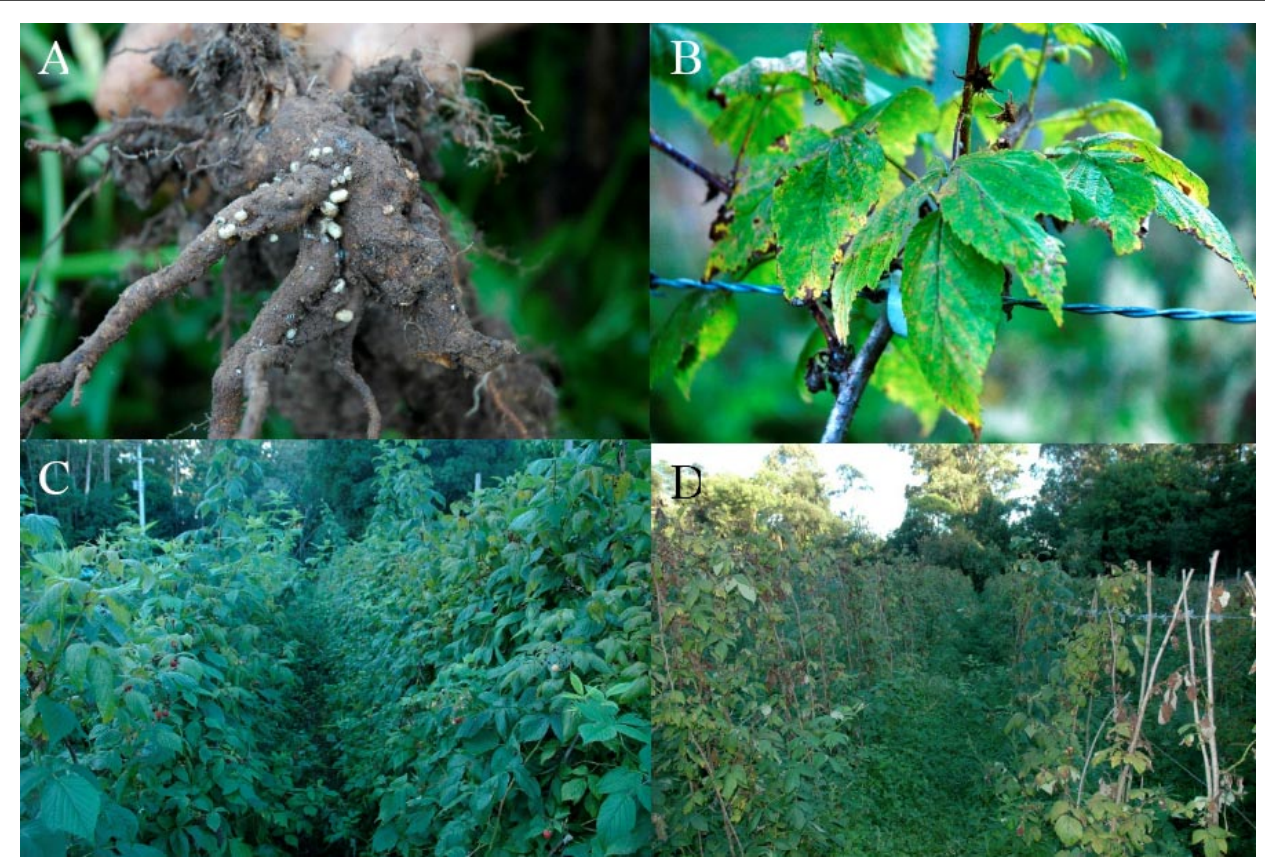

Figure 1 - A) Cysts of Brazilian ground pearl Eurhizococcus brasiliensis (Hemiptera: Margarodidae) in raspberry (Rubus idaeus L.) roots; B) Raspberry leaves showing symptoms of $\boldsymbol{E}$. brasiliensis attack; (C-D) raspberry crops with (D) and without (C) symptoms of $\boldsymbol{E}$. brasiliensis attack.

\section{ACKNOWLEDGEMENTS}

The authors thank CNPq for funding support. They thank the farmers of the Berry Farmers Association of Vacaria (APPEFRUTAS) for their cooperation and assistance with the research, and Aline Nondillo for identifying $L$. micans.

\section{REFERENCES}

ANTUNES, L.E.C. Amora-preta: nova opção de cultivo no Brasil. Ciência Rural, v.32, n.1, p.151-158, 2002. Available from: $<$ http://www.scielo.br/scielo.php?script=sci_arttext\&pid=S010384782002000100026\&lng=en\&nrm=iso $>$. Accessed: Mar. 10, 2011. doi: 10.1590/S0103-84782002000100026.

ANTUNES, L.E.C. Sistema de produção do Mirtilo. Pelotas: Embrapa Clima Temperado, 2007. (Sistemas de Produção, 8). Available from: http://sistemasdeproducao.cnptia.embrapa.br. Accessed: Mar. 10, 2011.

ANTUNES, L.E.C. Sistemas de produção da amoreira-preta. Pelotas: Embrapa Clima Temperado, 2008. (Sistemas de Produção, 12). Available from: <http://sistemasdeproducao.cnptia.embrapa.br $>$. Accessed: Mar. 10, 2011

AZEVEDO-FILHO, W.S. de et al. Curadoria da coleção entomológica da Embrapa Uva e Vinho. Bento Gonçalves: Embrapa Uva e Vinho, 2007. 10p. (Comunicado Técnico, 77).

BEN-DOV, Y. A systematic catalogue of the scale insect Family Margarodidae (Hemiptera: Coccoidea) of the world Wimborne: Intercept, 2005. 400p.
BOTTON, M. et al. Bioecologia e controle da pérola-daterra Eurhizococcus brasiliensis (Hempel, 1922) (Hemiptera: Margarodidae) na cultura da videira. Bento Gonçalves: Embrapa Uva e Vinho, 2000. 23p. (Circular Técnica, 27).

BOTTON, M. et al. Pérola-da-terra. In: SALVADORI, J.R. et al. (Org.). Pragas de solo no Brasil. Passo Fundo / Brasília: Embrapa Trigo, Embrapa Agropecuária Oeste, 2004. p.457-476.

BOTTON, M. et al. Efeito da cobertura vegetal sobre a pérola-daterra (Hemiptera: Margarodidae) na cultura da videira. Acta Scientiarum. Agronomy, v.32, p.681-684, 2010a. Available from: $<$ http://www.scielo.br/scielo.php?script=sci_arttext\&pid=S180786212010000400016\&lng=en\&nrm=iso >. Accessed: Mar 10, 2011. doi: 10.4025/actasciagron.v32i4.4773.

BOTTON, M. et al. Use of soil insecticides to control the Brazilian ground pearl in vineyards. Revista Colombiana de Entomología, v.36, p.20-24, 2010b. Available from: <http://www.scielo.org.co/ scielo.php? script=sci_arttext\&pid=S 0120 04882010000100005\&lng=en\&nrm=iso>. Accessed: Mar 10, 2011.

GALLOTTI, B.J. Contribuição para o estudo da biologia e para o controle químico do Eurhizococcus brasiliensis (Hempel, 1922). 1976. 63f. Master dissertation in Entomology - Universidade Federal do Paraná, PR.

GARRIDO, L.R. et al. Guia de identificação de doenças, pragas e deficiências nutricionais na cultura da videira. Bento Gonçalves: Embrapa Uva e Vinho, 2008. 78p. 
HAJI, F.N.P. et al. Cochonilha pérola-da-terra: praga emergente na cultura da uva, no submédio do Vale do São Francisco. Petrolina: Embrapa Semi-Árido, 2004. 5p. (Circular Técnica, 78).

KONDO, T. Las Cochinillas de Colombia (Hemiptera: Coccoidea). Biota Colombiana, v.2, n.1, p.31-48, 2001.

LOURENÇÃO, A.L. et al. Ocorrência de Eurhizococcus brasiliensis (Hempel) (Homoptera: Margarodidae) em videira no município de Louveira, Estado de São Paulo. Bragantia, v.48, n.2, p.205-208, 1989. Available from: <http:// www.scielo.br/scielo.php?script=sci_arttext\&pid=S000687051989000200005\&lng=en\&nrm=iso $>$. Accessed: Mar 10, 2011. doi: 10.1590/S0006-87051989000200005.

NAVA, D.E. et al. Insetos praga e seu controle. In: ANTUNES, L.E.C.; RASEIRA, M.C.B. (Org.). Cultivo de amoreirapreta (Rubus spp.). Pelotas: Embrapa, 2007. p.79-94.

NINO, A.F.P. et al. Sistema de produção da framboeseira. Pelotas: Embrapa Clima Temperado, 2007. (Sistemas de Produção, 9). Available from: <http://sistemasdeproducao.cnptia.embrapa.br>. Accessed: Mar. 10, 2011.
PAGOT, E.; HOFFMANN, A. Produção de pequenas frutas no Brasil. In: SEMINÁRIO BRASILEIRO SOBRE PEQUENAS FRUTAS, 2003, Vacaria, RS. Anais... Bento Gonçalves: Embrapa Uva e Vinho, 2003. 64p. (Documentos 37).

PAGOT, E. Associação dos produtores de pequenas frutas de Vacaria - APPEFRUTAS, 2009. Accessed: Feb. 20, 2011. Online. Available from: <http://www.appefrutas.com.br/>.

SACCHET, F. et al. Ant species associated with the dispersal of Eurhizococcus brasiliensis (Hempel in Wile) (Hemiptera: Margarodidae) in vineyards of Serra Gaúcha, Rio Grande do Sul. Sociobiology, v.54, p.943-954, 2009.

SORIA, S.J.; GALLOTTI, B.J. O margarodes da videira Eurhizococcus brasiliensis (Homoptera: Margarodidae): biologia, ecologia e controle, no Sul do Brasil. Bento Gonçalves: Embrapa Uva e Vinho, 1986. 22p. (Circular Técnica, 13).

TEIXEIRA, I. et al. Avaliação de inseticidas visando ao controle de Eurhizococcus brasiliensis (Hemiptera: Margarodidae) em novos plantios de videira. Neotropical Entomology, v.31, n.3, p.457-462, 2002. Available from: <http://www.scielo.br/ sciel o.ph p ? s c ri p t = sci_art text \& pid=S 1519 566X2002000300017\&lng=en\&nrm=iso>. Accessed: Mar. 30, 2011. doi: 10.1590/S1519-566X2002000300017. 